\title{
Ergenlerde Dinin Hayatın Anlamına Olan Etkisi Üzerine Bir Araştırma *
}

\author{
Yasin Kuruçay \\ Dr., Milli Eğitim Bakanlı̆̆ (ROR ID: 00jga9g46) \\ Atatürk Anadolu Lisesi \\ PhD., Ministry of National Education, Atatürk Anadolu High School \\ Bursa/Turkey \\ yasinrehber@hotmail.com \\ ORCID: 0000-0002-1795-704X
}

\section{A Research on the Effect of Religion on the Meaning of Life in Adolescents \\ Abstract}

Almost everyone emphasizes that we live in an age of crisis. The deepest symptoms of the crisis are also observed in adolescents. It is an important task to analyze the crises experienced correctly and to put forward possible solutions to live in a better world. To fulfil this task, it is necessary to analyze our age and the conditions affecting it properly.

Young people/adolescents make up about a third of the world's population. Adolescence is a bridge between our yesterday and our tomorrow, the point where our past and our future connect. Adolescence is the peak of efforts to give meaning to life. In adolescence, many problems such as alienation, suicide, unhappiness and insecurity are based on a sense of meaninglessness. Finding a real meaning for life is the main feature of adolescence. Adolescence is the process of forming an identity. The identity formed in this period affects the whole life. In this process, adolescents begin to question their culture, social values, beliefs and legal rules. The purpose of this question is to reach the basic values and a basic source of meaning that will make life positive. The thought of questioning the life of adolescents and their efforts for a better and happier life are the most important indicators of the search for meaning.

The content of the concept of meaning is difficult to determine, but there is no other concept to replace meaning. Meaning is about whether life is worth living or not, living humanely, living for supreme purposes. Understanding means that to grasp the essence of something in it and to be aware of the things what it is related to. Understanding something is finding something from ourselves and discovering ourselves outside of ourselves. The Meaning of Life refers to having a life goal that enables people to make sense of their lives. People who reach meaning can develop their potential, find solutions to their problems, and establish healthy relationships with others. In this way, they maintain their lives in integrity.

\footnotetext{
Bu çalışma 13.11.2019 tarihinde tamamladığımız “Ergenlerde Dindarlık ve Hayatın Anlamı Arasındaki Çok Yönlü İlişki Üzerine Bir Araştırma" başlıklı doktora tezi esas alınarak hazırlanmıştır/This article is extracted from my doctorate dissertation entitled "A Research on the Multi-Directional Relationship Between Religiousness and the Life Meaning in Adolescents", Since the ethics committee decision was not mandatory at the time the thesis was prepared, ethical statement wasn't taken. (Ph.D. Dissertation, Uludağ University, Bursa/Turkey, 2019).

İtihal Taraması/Plagiarism Detection: Bu makale intihal taramasından geçirildi/This paper was checked for plagiarism Geliş/Received:09 Mayıs/May 2020|Kabul/Accepted:02 Eylül/Septenber 2020| Yayın/Published: 20 Eylül/September 2020 Atıf/Cite as: Yasin Kuruçay, "Ergenlerde Dinin Hayatın Anlamına Olan Etkisi Üzerine Bir Araştırma = A Research on the Effect of Religion on the Meaning of Life in Adolescents", Eskiyeni 41 (Eylül/September 2020), 599-622. https://doi.org/10.37697/eskiyeni.734877

Copyright @ Anadolu İlahiyat Akademisi/Anatolian Theological Academy, 06050, Ankara, Turkey | www.anilakademi.com CC BY-NC 4.0 | This paper is licensed under a Creative Commons Attribution-NonCommercial License
} 
Religion is a phenomenon that prevents meaninglessness, adds meaning to life, helps all dimensions of life and existence, and it is very important for adolescences. Religious principles and religious values provide alternatives that will make life meaningful and happy for adolescents. Because meaning is the most basic fact of life and religion is the most basic fact of meaning. Life has individual and social goals in the meaning map of religion. Religiosity is a personality trait that gives purpose to life, provides a perspective that will make the problems experienced meaningful, and allows coping with shocking life events. Research has shown that there is a positive relationship between religiosity and well-being, psychological health, happiness and meaningful life.

Our research focuses on the contributions of religion on search for meaning and leading a meaningful life in adolescents. In this research, it has been proven that the opinions of the adolescents participating in the interview about meaning and meaninglessness were compatible with previous researches and other research results in the literature. The research was based on the grounded theory approach of qualitative research methods. In this context, half-structured interview with 28 adolescence, aged between 18 and 24, reached by purposive sampling method was carried out. UNESCO which is United Nations Educational, Scientific and Cultural Organization and Turkey Statistical Institute TÜIK make research on youth. Both institutions define the age of 16-25 as adolescence or youth. In this research, taking into account the data of two institutions, the age range of 18-24 has been centred. Many scientific studies related to adolescence take this age range into account.

Content analysis and descriptive analysis were carried out in the study. The NVivo 12 programme is utilized for alyzingthe data. The findings was discussed based on the relevant literature and recommendations were made for further studies.

Almost no research studies are investigating the relationship between meaning, adolescence and religiosity in the field of both psychology and psychology of religion in Turkey. This situation shows the importance of our study. It is possible to use the results of this study to develop main policies in the social, cultural and educational field regarding adolescents.

\section{Keywords}

Psychology of Religion, Religiosity, Adolescence, Meaning, Search for Meaning, Religion

\section{Öz}

\section{Ergenlerde Dinin Hayatın Anlamına Olan Etkisi Üzerine Bir Araştırma}

Hemen herkes krizler çağında yaşadığımıza dair derin vurgular yapmaktadır. Krizin en derin belirtileri de ergenler üzerinde gözlemlenmektedir. Yaşanan krizleri doğru tahlil etmek ve olası çözüm önerilerini ortaya koymak daha iyi bir dünyada yaşamak adına önemli bir görevdir. Bu görevi yerine getirmenin şartı da çağımızı ve ona rengini veren koşulları sağlıklı bir şekilde analiz etmek ile mümkündür.

Dünya nüfusunun yaklaşı üçte birini gençler/ergenler oluşturmaktadır. Ergenlik dünümüz ile yarınımız arasında bir köprü, geçmişimizle geleceğimizin bağ kurduğu noktadır. Ergenlik dönemi hayata anlam verme çabalarının zirveye çıktığı dönemdir. Bu dönemde yaşanan yabanc1laşma, intihar, mutsuzluk ve güvensizlik gibi pek çok sorunun kaynağında anlamsızlık duygusu vardır.

Hayatta gerçek bir anlam bulmak ergenlik döneminin en temel özelliğidir. Ergenlik kimliğin oluşma sürecidir. Bu dönemde oluşan kimlik tüm hayatı etkilemektedir. Bu süreçte ergenler içinde bulundukları kültürü, toplumsal değerleri, sahip oldukları inançları ve yasal kuralları sorgulamaya başlar. Bu sorgulamanın amacı hayatı olumlu hale getirecek temel değerlere ve 
temel bir anlam kaynağına ulaşmaktır. Ergenlerdeki hayatı sorgulama düşüncesi, daha iyiye ve daha mutlu bir hayata doğru yaptıkları çabalar anlam arayışının en önemli göstergeleridir.

Anlam kavramının içeriğini anlamak ve tanımlamak zordur. Buna karşın onun verdiği anlamı kapsayan başka bir kelime de yoktur. Anlam kavramı, Abdulkerim Bahadır'ın yerinde ifadesiyle, hayatın yaşamaya değer olup olmadığıyla, insanca yaşamayla, yüce amaçlar için yaşamakla ilgilidir. Bir şeyi anlamak o şeyin özünü, ilişkili olduğu diğer varlıkları ve o şeyin ait olduğu bütünlüğü kavramak anlamına gelir. Anlama faaliyeti anlaşılan şeyde kendi hayatımızdan, duygu ve düşüncelerimizden birşeyler bulmayı ifade eder. Varlığımızın, bizim dışımızdaki varlıklar ile olan ilişkisini ve anlamını keşfetmeyi ifade eder. Hayatın anlamı insanların "ne için?" yaşadığını gösteren, hayatının anlamlı ve değerli olmasını sağlayan hedeflere sahip olmasıyla ilişkilidir. Çünkü insanlar anlamlı bir hayata ulaştıktıklarında potansiyellerini geliştirebilir, karşı karşıya kaldığı problemlere çözümler üretebilirler. Diğer insanlarla ve varlıkla doğru bir ilişki kurabilirler. Böylece yaşam bütünlüklerini korumuş olurlar.

Din anlamsızlığı önleyen, hayata anlam katan, tüm yaşam kalitesi ve varoluş boyutlarına yardım eden bir olgudur ve bu gençler için çok önemlidir. Dini ilkeler ve dini değerler ergenler için, hayatı anlamlı ve mutlu kılacak alternatifler ortaya koyar. Çünkü anlam hayatın, din de anlamın en temel ögesidir. Dinin anlam haritasında yaşamın bireysel ve toplumsal amaçları vardır. Dindarlık; hayata amaç veren, yaşanan sorunları anlamlı kılacak bir bakış açısı sağlayan, sarsıcı yaşam olayları ile başa çıkmayı sağlayan bir kişilik özelliğidir. Yapılan araştırmalar şunu göstermiștir: Dindarlık ile iyi oluş, psikolojik sağlık, mutluluk ve anlamlı bir hayat arasında pozitif bir ilişki vardır.

Araştırmamız ergenlerde dinin anlam arayışına ve anlamlı bir hayat sürmeye katkılarını konu edinmektedir. Araştırmada mülakata katılan ergenlerin anlam ve anlamsızlık ile ilgili görüşlerinin literatürdeki tanımlar ve birçok araştırma sonucu ile uyumlu olduğu görülmüştür. Araştırma nitel araştırma yöntemlerinden kuram oluşturma yaklaşımına dayalı olarak gerçekleştirilmiştir. Bu kapsamda amaçlı örnekleme yöntemi ile ulaşılan, yaşları 18 ile 24 arasında değişen 28 kişiyle yarı yapılandırılmış görüşmeler gerçekleştirilmiştir. Birleşmiş Milletler Eğitim, Bilim ve Kültür Örgütü olan Unesco ve Türkiye İstatistik Kurumu TÜiK gençlik üzerine araştırmalar yapmaktadır. Her iki kurum 16-25 yaş arasını ergenlik ya da gençlik dönemi olarak tanımlamaktadır. Bu araştırma da iki kurumun verilerini dikkate alarak 18-24 yaş aralığını merkeze almıştır. Ergenlik dönemiyle ilgili birçok bilimsel araştırma bu yaş aralığını dikkate almaktadır.

Araştırmada içerik analizi ve betimsel analiz yapılmıştır. Verilerin analizinde NVivo 12 programından faydalanılmıştır. Bulgular ilgili literatüre dayalı olarak tartışılmış ve ileri çalışmalar için önerilerde bulunulmuştur.

Türkiye'de gerek psikoloji gerekse din psikolojisi alanında anlam, ergenlik ve dindarlık ilişkisini araştıran çalışmalar neredeyse yok denecek kadar azdır. Bu durum çalışmamızın önemini göstermektedir. Bu çalışmanın sonuçlarını ergenlerle ilgili sosyal, kültürel ve eğitsel alanda ana politikalar geliştirmek için kullanmak mümkündür.

\section{Anahtar Kelimeler}

Din Psikolojisi, Dindarlık, Ergenlik, Anlam, Anlam Arayışı, Din

\section{Giriş}

Bu çalışma ergenlik dönemi özelliklerini, ergenlerin çağımızda karşı karşıya kaldığı problemleri ve bu problemlerin neden olduğu sonuçları ve dinin/dindarlığın, ergenlerin bu sorunlarla başa çıkmalarına ne ölçüde katkı sağladığını ortaya koymayı amaçlamaktadır. 
Günümüz medeniyetinin ergenler için ahlaki, felsefi ve psikolojik açlığa neden olması psikologlar için sarsıcı bir durumdur. Refah toplumunda birçok genç, anlamlı ve değerli bir hayat tarzından gittikçe uzaklaşmaktadır. ${ }^{1}$

Anlam ve din hayatın temel iki ögesidir. Din hem hayata anlam katma hem de anlamsızlığa bağlı sorunların ortaya çıkmasına engel olma açısından gençlere destek olabilir. İslam dini de hayatı, dünya-ahiret dengesiyle açıklayarak her türlü soru ve sorunu ilahi bir plan doğrultusunda anlamlandırır. Dinin hayata anlam katan ilkeleri bu sorunları ve zorlukları insanların dini-kişisel gelişimleri açısından faydalı olabilecek bir bağlamda ele alarak ergenlere anlamlı bir hayatın kapılarını açar. Dini başa çıkma stratejileri ergenlerin yaşadıkları sorunlara dair bilişsel açıklamalar yaparak, duygusal ve davranışsal önerilerde bulunarak ve pratik öneriler getirerek çözüm önerileri sunar.

Dünyada din ve dindarlık ile ilgili deneysel araştırmalar yıllar geçtikçe yaygınlaşmaktadır. Akademik araştırma motorlarından Jstor sitesine dindarlık kavramıyla ilgili olarak, religiousity ve piety yazdığımızda toplamda 180 bin araştırma sonucu, din-religion kavramını yazdığımızda da yaklaşık 1,3 milyon sonuç çıkmaktadır. Google akademik sitesinde ise en az iki kat fazla sonuç çıkmaktadır. ${ }^{2}$ Pek çok bilim adamına göre psikoloji ve bilim, pozitivist bilim anlayışının göz ardı ettiği konuları da incelemelidir. Maslow bilimin, din ve değerler alanını içine alarak yeniden şekillenmesi gerektiğini ifade eder. ${ }^{3}$

Türkiye'de din psikoloji çalışmalarında ergenlik dönemiyle ilgili olarak, hem anlam hem de din kavramını birlikte ele alan ve bu iki kavramın birbiriyle ilişkisini araştıran çalışmalar yok denecek kadar azdır. ${ }^{4}$ Bu durum çalışmamızın önemini göstermektedir. Araştırmanın temel problemi, "Ergenlerde dinin ve dindarlı̆̆ın anlamlı bir hayat sürmeye katkısı nedir?"dir.

\section{Ergenlik Döneminde Dini Hayat ve Anlam Arayışı}

Ergen kavramı Latincede "büyümek, olgunlaşmak" anlamında kullanılan "adolescence" kelimesiyle aynı anlamı taşır. Ergenlik "bireyde gözlenebilen hızlı ve sürekli bir gelişme evresi” olarak ifade edilir. ${ }^{5}$ Köknel ve Yavuzer gibi bilimadamları,

1 Abraham Maslow, Dinler, Değerler, Doruk Deneyimler, çev. H. Koray Sönmez (ìstanbul: Kuraldışı Yayıncılık, 1996), 31.

2 09.03.2020 tarihinde yapılan araştırma sonuçlarına göre yazılmıştır. Arama butonlarına "Religion, religious, piety ve religiousity" kavramları yazılarak araştırma yapılmıştır.

3 Abraham Maslow, Dinler, Değerler, Doruk Deneyimler,18.

4 Özlem Kızılırmak, Genç Yetişkinlerde Yaşamda Anlamın Maneviyat ve Kişilik Özellikleri Açısından İncelenmesi (Ankara: Gazi Üniveristesi, Eğitim Bilimleri Enstitüsü, Yüksek Lisans Tezi, 2015); Zeliha Çamur, Yaşamda Anlam ve Dindarlık İlişkisi (Samsun: Ondokuz Mayıs Üniversitesi Sosyal Bilimler Enstitüsü, Yüksek Lisans Tezi, 2014); Cüneyd Aydın, İnsanın Anlam Arayışı ile Yeni Çağ İnanışları Arasındaki İlişki (Samsun: 19 Mayı Üniversitesi Sosyal Bilimler Enstitüsü, Doktora Tezi, 2015).

5 Laurence Steinberg, Ergenlik, çev. Figen Çok (İstanbul: İmge Kitapevi, 2007), 21. 
ergenlik döneminin 12-21 yaş aralığ1 olduğunu ifade etmişlerdir. ${ }^{6}$ Unesco ergenlik dönemini 15-25 yaşları arası olarak belirtmiştir. ${ }^{7}$ TÜIK gençlik araştırmalarını yaparken 16-24 yaş arası kitleyi araştırmaktadır. ${ }^{8}$ Gerek gelişim psikologlarının görüşleri gerekse ulusal ve uluslararası kurumların araştırmaları dikkate alınarak bu araştırmada 16-24 yaş arası ergenlerle çalışılmıştır.

Ergenlik döneminde zihinsel gelişmeye paralel olarak dini şuur da gelişmeye başlar. ${ }^{9}$ Ergenlik dönemi hem dini arayışların ve ilgilerin büyük ölçüde arttığı hem de dinin hükümlerine, ilkelerine ve kurallarına karşı sorgulayıcı bakış açısının yoğunlaştı̆̆ı bir dönemdir. Ergenler genellikle yaradılışına uygun olarak Allah'a, dini duygulara ve dinin anlam kaynaklarına yönelim gösterirler. ${ }^{10} \mathrm{Bu}$ dönemin sonunda gençler, aileden aldıkları inançları devam ettirir ya bu inançları bireysel olarak yeniden yapılandırır ya da nadiren de olsa dini reddetme eğilimi gösterirler. ${ }^{11}$

Ergenlik dönemindeki kimlik oluşturma süreci, aynı zamanda bu dönemde sıklıkla yaşanılan anlamsızlıklarla başa çıkma sürecini, anlamı arama ve koruma çabalarını da içinde barındırır. Bu açıdan bakıldığında ergenlik, "anlam arayışının ve mutlu olma arzusunun en üst düzeyde olduğu dönemdir."12 Bu dönemde din, ergenlerin kimlik gelişimine birçok açıdan olumlu katkılar sağlar. Hökelekli’nin ifadesiyle "Din insanlarda psikolojik bir koruma ve destekleme görevi gören, kişinin benliğiyle ve toplumla uyumunu kolaylaştıran, kişiye olumlu ve iyimser bir kişilik oluşturmasında destek olan bir ögedir."13

Ergenlik döneminde ortaya çıan imani şüphe ve tereddütlere karşı dinin ortaya koyduğu teorik açılama ve anlamlandırmalar gençler üzerinde etkili olmaktadır. ${ }^{14}$ Dinin kavramsal çerçeveleri ergenlere bazı değerler sunar, aynı değerler ve uygulamalar etrafında birleşen bir topluluk içinde olma ve bu topluluğa katılma imkânı verir. Böylece ergenler yaşadığı sosyolojik atmosferde bireysel varlığının bir anlamı ve değeri olduğunu kavrar ve toplum içindeki statüsünü belirleyebilir. ${ }^{15}$ Din ile insan kişiliği arasında sıkı bir ilişki vardır. Bilim ve din, insanın karmaşık kişiliğini anlamaya ve açıklamaya çalışmaktadır. 16 "Din kişiliğin kapasitelerinden

\footnotetext{
Özcan Köknel, Cumhuriyet Gençliği ve Sorunları (İstanbul: Cem Yayınevi, 1981), 34; Haluk Yavuzer, Gençleri Anlamak (İstanbul: Remzi Kitabevi, 2015),264.

7 Bk. Haluk Yavuzer, Çocuk Psikolojisi (İstanbul: Remzi Kitapevi, 1999).

8 Türkiye İstatistik Kurumu (TÜIK), İstatistiklerle Gençlik 2016 http://www.tuik.gov.tr/PreHaberBultenleri.do?id=24648 (04.01.2018)

9 Hayati Hökelekli, Din Psikolojisi (Ankara: TDV Yayınları. 2013); Antoine Vergote, “Çocuk ve Din”, çev. Erdoğan Fırat, Ankara Üniversitesi İlahiyat Fakültesi Dergisi 22 (1978), 315-329.

10 Hökelekli, Din Psikolojisi, 269.

11 Hökelekli, Din Psikolojisi, 271-272.

12 Dennis Prager, Mutluluk Ciddi Bir Sorundur, çev. Orhan Tuncay (İstanbul: Alkım Yayınevi, 1998), 125.

13 Hayati Hökelekli, Din Psikolojisi, 285.

14 Hayati Hökelekli, Gençlik, Din ve Değerler Psikolojisi (İstanbul: Dem Yayınları, 2006), 15.

15 Bk. M. Naci Kula, Gençlik Döneminde Kimlikve Din (İstanbul: Ayışı̆̆ı Yayıncılık, 2001).

16 Michal Stríženec, "Dindarlık ve Bilişsel Süreçler", çev. Abdulvahid Sezen, Dinbilimleri Akademik Araştırma Dergisi 10/3 (2010), 274.
} 
güç alırken; kişilik, dinin insan ruhunda alacağı biçimi belirlemekte ve kişiye has davranış tarzlarının oluşmasında etkili olmaktadır."17

Dinin kurallarını bir şekilde dikkate alan kişiler, dikkate alma dereceleri farklı da olsa dindarlık kavramı içerisinde değerlendirilebilmektedir. Kişisel yaşamında ve sosyal yaşantısında dinin kurallarını benimseyen ve bunlara uymaya gayret eden kişiye dindar denilir. ${ }^{18}$ "Dindarlık, bireyin öznel dinsel inanç ve pratik algıları sonucunda benliği ve kişiliğiyle bütünleşmiş karmaşık bir psiko-sosyo-teolojik olgudur." ${ }^{19}$ Vergote'a göre dindarlık, varoluşun kaynağı olarak Tanrı'yı görmek ve O'nu iyilik yapmayı seven bir güç ya da kudret olarak kabul etmektir. ${ }^{20}$

\section{Dinin Hayatın Anlamına Etkisi}

İnsanlara yeryüzü cenneti vadeden modern Batı uygarlığı, yaşanan kimlik krizi ve toplumsal bunalımları çözemediği gibi birçok sorunun da tetikleyicisi olarak görülmektedir. ${ }^{21}$ Sürekli tüketim, lüks ve eğlenceye yönelmek ergenlerin kendi benliğine dönmesi için ona boş vakit bırakmamakta, hayatın anlamını unutturmakta ve özgürlüğünü maddi dünyanın ayakları altına almaktadır. ${ }^{22}$ Amaca ulaşmada grupsal, toplumsal ve ilahi desteği göz ardı ederek tüm planlamayı, uygulamayı ve sonuçları değiştirmeyi bireylerin sorumluluğuna yükleyen Batılı "yeterlilik” algılayışı, ergenleri hedefe ulaştırmamakta ve yalnızlaştırmaktadır. Hayat; kültürel, ekonomik, sosyal, siyasal, psikolojik çok boyutlu bir süreçtir. Bu süreçte sayısız kişi ve kurumun hayata ve gençlere dair planları, kurguları, hedefleri ve tuzakları vardır. Hayatın çok boyutlu işleyişine ve her türlü sorununa karşı kendini tek başına yeterli görmek, gençlerde yanılsamaya neden olmaktadır. Sorunlarla tek başına başa çıamamak ve hayatın bütüncül işleyişini tam olarak kavrayamamak gençlerin içe dönmelerine ve umutsuzluğa kapılmalarına neden olmaktadır. Bu da "anlam(sılık)" sorununa neden olmaktadır. ${ }^{23}$ Günümüzde sınırsız özgürlüğe kavuşan ergenler her türlü bilgiye ve veriye ulaşma, istediği yerlere gitme, bağımsız hareket edebilme gibi araçlara sahiptir ama kalıcı anlamlara ve amaçlara sahip değildir. ${ }^{24}$ Anlam kavramı ilk kez İlkçağ düşünürü Herakleitos'un (İ.Ö. 540-475) logos kavramıyla kullanılmıştır. Antik Yunan'da logos kavramı; anlam, söz, ölçü ve oran gibi anlamlarda kullanılmaktadır. ${ }^{25}$ Bununla birlikte anlam kavramını doğrudan yaşam ile ilgili olarak kullanan ilk düşünür Sokrates'tir.

17 İbrahim Gürses, Dindarlıkve Kişilik (Bursa: Emin Yayenvei, 2010), 32.

18 Vecdi Bilgin, “Popüler Kültür ve Din: Dindarlığın Değișen Yüzü”, Uludağ Üniversitesi İlahiyat Fakültesi Dergisi 12/1 (2003), 195.

19 Mustafa Koç, "Dindarlık İle Benlik Saygısı Arasındaki İlişki: Yetişkinler Üzerine Ampirik Bir Araştırma”, Uludağ Üniversitesi İlahiyat Fakültesi Dergisi 18/1 (2009), 476.

20 Antoine Vergote, Din, İnançve İnançsızlık, çev. Veysel Uysal (İstanbul: Marmara Üniversitesi İlahiyat Vakfı Yayınları, 1999), 88.

21 Rene Guenon, Modern Dünyanın Bunalımı, çev. Mahmut Kanık (İstanbul: Hece Yayınevi, 2005), 37-53.

22 Ziyauddin Serdar, Postmodernizm ve Öteki (İstanbul: Söylem Yayınları, 2001), 40-42.

23 Charles Richard Snyder vd. "Hopeful Choices: A School Counselor's Guide To Hope Theory”. Professional School Counseling, 5/5 (2002), 298-307.

24 Viktor E Frankl, Duyulmayan Anlam Çığlı̆̆ çev. Selçuk Budak (Ankara: Öteki Yayınevi, 1999), 129.

25 Walter Kranz, Antik Felsefe, çev. Suad Y. Baydur (İstanbul: Sosyal Yayınevi, 1994), 57. 
Sokrates hayatın anlamını bilgece yaşamada, kendini tanımada ve kendini bilmede bulmaktadır. ${ }^{26}$ "Anlam hayatın yaşamaya değer olup olmadığıyla, insanca yaşamayla, yüce amaçlar için yaşamakla ilgilidir." ${ }^{27}$ İnsanlar karşı karşıya kaldıkları problemleri anlamalarını sağlayacak bütüncül bir anlam sistemine ihtiyaç duyarlar. Anlam Baumeister'e göre psikolojinin ana konusudur. O'nun ifade ettiği şekliyle "dünyada her şey için kullanılabilen en iyi araçtır". ${ }^{28}$ Çünkü anlam kavrami; hedef, inanç, iyi oluş, tatmin olma, varoluşun özü ve hayatın amacı gibi pek çok psikolojik yapıyı içinde barindırır. ${ }^{29}$

İnsanın en belirgin özelliği sürekli bir anlam arayışı içinde olmasıdır. ${ }^{30} \mathrm{ilk} \mathrm{insan-}$ dan günümüze kadarki tüm insani çabalar anlam arayışııın yansımasıdır. ${ }^{31}$ Anlam arayışı logoterapi ekolünün anahtar kavramlarından biridir. Logoterapi ekolüne göre insan, anlam ötesi bir varoluşa yönelik güçlü bir arzu taşır. Anlam ötesi varoluşa ait olan bu duygu aynı zamanda dini inancı da ifade eder. Aşkın bir varoluşa yönelmede, sosyal çevrenin etkisi ve kişisel yatkınlıklar etkili olsa da, bu yönelimin temel sebebi insan doğasında varolan manevi-dini yönelimlerdir. ${ }^{32}$ Insan anlam-üstü ya da anlamötesi bir varlığa yani hayata anlam veren Tanrı'ya ve kutsala yönelim gösteren bir özelliğe sahiptir. Anlam-ötesi insan hayatının en son, en öz ve en bütüncül anlamını ifade eder. İnsan bu anlamı tam olarak kavrayamaz. Bu gerilimin çözümü inanç ile mümkündür. ${ }^{33}$ İnanç insanın yaradılış-varolma gerekçesini açıklayarak, hayatı tüm boyutlarıyla anlamlandırarak, zorluk ve sıkıntıların anlamını ve sonuçlarını açıklayarak bu gerilimlerin çözümüne katkı sağlar.

Ergenler hayatına anlam katacak, hayatını değerli kılacak bir amaç ararlar. ${ }^{34} \mathrm{Er}-$ genlerin iç dünyalarına ve hayat tecrübelerine baktığımızda aslında anlam arayışının ve anlam oluşturma çabalarının olmadığı neredeyse hiçbir davranış ve varoluş olmadığını görürüz.

Hayat anlamı salt soyut ve teorik bir ilke değildir, günlük hayatımızın içindedir. Hayatın anlamı, insanların hayatını anlamlandırmasını sağlayan bir misyona, amaca veya kapsayıcı bir yaşam hedefine sahip olma derecesini ifade eder. ${ }^{35}$ Hayatın anlamı

26 Sokrates, Sokratesin Savunmasl, çev. Teoman Aktürel (ìstanbul: Remzi Kitabevi, 2004), 13-14.

27 Abdülkerim Bahadır, Hayatın Anlam Kazanmasında Psiko-sosyal Faktörler ve Din (Bursa: Uludağ Üniversitesi Sosyal Bilimler Enstitüsü, Doktora Tezi, 1999), II.

28 Roy F. Baumeister-Michael J. MacKenzie, "Meaning in Life: Nature, Needs, and Myths", in Meaning in Positive and Existential Psycholog (ed.), Batthyany A.-P. Russo Netzer (New York: Springer Press, 1991), 357358.

29 Crystal L. Park, "Din ve Anlam", çev. İlker Yenen Din ve Maneviyat Psikolojisi Yeni Yaklaşımlar ve Uygulama Alanları içinde, (ed.), Raymond F. Paloutzan-Crystal L. Park (Ankara: Phoenix Yayınevi, 2013), 29.

30 Frankl, Duyulmayan Anlam Çı̆̆lı̆ı̆, 25.

31 Bahadır, Hayatın Anlam Kazanmasinda Psiko-sosyal Faktörler ve Din, 1999, I.

32 Abdülkerim Bahadır, "Hayatın Anlam Kazanmasında Psiko-sosyal Faktörler ve Din", Selçuk Üniversitesi Sosyal Bilimler Enstitüsü Dergisi 6 (2000), 194.

33 Bahadır, Hayatin Anlam Kazanmasinda Psiko-sosyal Faktörler ve Din, (1999), 20.

34 Yllmaz Özakpınar, İnsan, İnanan Bir Varlk (İstanbul: Ötüken Neşriyat, 1999), 41.

35 Michael F. Steger, "Making Meaning in Life", Psychological Inquiry 23(4) (2012), 381-385. 
bulunduğunda kişiliği geliştirecek olan anahtar elde edilmiş olur. ${ }^{36}$ Hayatın anlamı ya da yaşamda anlam kavramı günümüzde daha çok Pozitif Psikolojinin içerisinde ele alınmaktadır. ${ }^{37}$ Hayatın anlamı psikologlar tarafından mutluluk, ${ }^{38}$ iyi oluş ${ }^{39}$ ve umut ${ }^{40}$ gibi kavramlar ile ilişkilendirilmiştir. Hayatın anlamı pozitif duygular ile olumlu bir ilişki, negatif duygular ile olumsuz bir ilişki gösterir. ${ }^{41}$ Anlam duygusuna sahip olan insanlar; hayatın bir amacı olduğunu düşünerek, bu amacı gerçekleştirecek bir çaba içerisinde olarak, yaşamlarını adayabilecekleri hedeflere sahip olarak yaşarlar. ${ }^{42}$

Din hayatın temel konularındaki anlamları ortaya koyarak insanlara ş̧ık olabilir. ${ }^{43}$ Din insanın nasıl yaşaması gerektiği ile ilgili ilkeleri ortaya koyarak ve hayat olaylarını yorumlayarak, ${ }^{44}$ akıl ile ulaşılamayan alanları açıklayarak, insana bu hayatla son bulmayacak değerleri ve ilkeleri göstererek sonsuz bir anlam sağlar ve ölümün ardındaki dünyayı aydınlatır. ${ }^{45}$

Din psikolojisi alanında yaptığı önemli çalışmalarla bilinen Fowler’a göre “iman, bir kişinin paylaşılan anlam ve gaye arka planına karşı diğer başkalarıyla kendisini ilişkili olarak görme tarzıdır" ${ }^{46}$ Fowler'a göre iman anlam ile doğrudan ilişkilidir ve insan anlam peşinde koşan tek varlıktır. ${ }^{47}$ İman hayatın bilişsel, duyuşsal ve davranışsal yönlerini kuşatan bir anlamlandırma sürecidir. Din, tüm hayat felsefelerinin en kapsamlı olanıdır. ${ }^{48}$ Pargament, dini "kutsalla ilişkili tarzda tezahür eden anlam arayışı" olarak tanımlar. ${ }^{49}$ Pargament'e göre insanlar yaşadıkları sürece anlam arayışı içerisindedirler ve insanlar dinin dışındaki anlam kaynaklarına da ulaşırlar. Ancak bu

36 Alfred Adler, Yaşamanin Anlam ve Amacı, çev. Kamuran Şipal (İstanbul: Say Yayınevi, 1998), 23-26.

37 Martin, E. P. Seligman - M. Csikszentmihalyi, “Positive Psychology: An Introduction”, American Psychologist, 55 (2000), 5-14.

38 Chamberlain, Kerry and Sheryl Zika, "Religiosity, Life Meaning and Wellbeing: Some Relationships in a Sample of Women", Journal for the Scientific Study of Religion 27/3 (Sep.1988), 411-420.

39 Emine Zehra Bilge, Liseli Gençlerde İç ve Dış Güdümlü Dindarlık ve İyilik Algıları (Eskişehir: Osmangazi Üniveristesi, Yüksek Lisans Tezi, 2013).

40 Feldman - Snyder, 2002; Joshua Hicks - Laura A King, "Meaning In Life And Seeing The Big Picture: Positive Affect and Global Focus", Cognition and Emotion 21/7 (November 2007), 1577-1584.

41 Martin, E. P. Seligman - M. Csikszentmihalyi, “Positive Psychology: An Introduction”, 5.

42 İrvin, D. Yalom, Varolusçu Psikoterapi, çev: Zeliha İyidoğan Babayigit (İstanbul: Kabalc1 Yayınları, 1999), 658-660.

43 Bk. Hans Küng - Karl Josef Kuschel, Evrensel Bir Ahlâka Doğru, çev. Nevzat Y. Aşıkoğlu vd. (Ankara: Gün Yayıncilik, 1995).

44 Leon Mckenzie "The purposes and scope of adult religious education”. In Handbook of Adult Religious Education, Ed. N. T. Foltz. Birmingham: AL. Religious Education Press (1986), 7-23.

45 Lev N. Tolstoy, İtiraflarım, çev. K. Aytaç (İstanbul: Furkan Yayınevi, 1997).

46 James, W. Fowler, Stages of Faith, The Psychology of Human Development and Quest for Meaning (San Francisco: Harper and Row, 1981), 4.

47 Abdulvahid Sezen, “Günümüz İnsanının Anlamsızlık Sorunu Bağlamında Frankl ve Fowler'da Bireyin Anlam Arayışı”, Sosyal Bilimler Araştırma Dergisi 7/14 (Eylül 2009), 195.

48 Gordon, W. Allport, Birey ve Dini, çev. Bilal Sambur (Ankara: Elis Yayınevi, 2004), 94-97.

49 Kenneth, I. Pargament, "The Psychology of Religion and Spirituailty? Yes Or No". The International Journal for The Psychology of Religion 9/1 (1999), 3-16.; Pargament, Kenneth, I, - H. G. Koenig - L. Perez, "The Many Methods of Religious Coping: Development and Initial Validation of The RCOPE”. Journal of Clinical Psychology 56(4) (2000), 519-543. 
anlam kaynaklarından hiçbiri dinin sağladığı etkililikte değildir. ${ }^{50}$ Dini inançlar ve yüksek anlam duygusu arasında sıkı bir ilişki vardır. ${ }^{51}$ Sorunlar ve gerilimlerle dolu olan bu dünyada, dünya ötesi bir anlam kaynağı olmadan kişiler ruhsal ve ahlaki özerklikleri için sağlıklı bir dayanak bulamazlar. İnsan psikolojisiyle ilgilenen hemen herkes dinin sadece tarihsel ve toplumsal değil aynı zamanda kişisel bir olgu olduğunu mutlaka göz önüne almak zorundadır. ${ }^{52}$

Ergenlerin bu dünyanın zorluklarına karşı koruyan içsel ve manevi bir tecrübeye ihtiyaçları vardır. Din açıklanması zor olaylara karşı dünyayı daha doğal ve normal olarak görmesini sağlayacak entelektüel bir temel oluşturmaktadır. ${ }^{53}$ Müslüman, Yahudi ve Hıristiyan öğrencilerden oluşan grupla yapılan bir çalışmada, yüksek dindarlık ile hayatın anlamı arasında olumlu ilişki bulunmuștur. ${ }^{54}$

İslam inancı inananların kişiliklerine etki etmektedir. İslam'daki iman esasları insan kişiliğinin temel taşlarıdır. Bu esaslar insanın duygularını, düşüncelerini, inanışlarını ve davranışlarını etkileyerek, insanın hayat felsefesini ve dünya görüşünü oluştururlar. İslam'a göre Allah'ın varlığı hayatın önemli bir anlamı ve amacı olduğunun işaretidir. Çünkü Allah hiçbir şeyi boş ve amaçsız yaratmamıştır (Kıyamet, 75/36). Allah her şeyi ve tabii ki insanı bir amaç için yaratmıştır. Bu amaç birçok alt amacı içinde barındırır. Ancak en üst amaç kulluk ve ilahi rızaya ermektir (Zariyat, 51/56). Allah'ın olduğu bir dünyada acının da, kederin de, sevincin de, mutluluğun da bir karşılığı ve anlamı vardır (Ali İmran, 3/191). Bu anlama sahip olmak hayatın olumlu ve olumsuz durumları karşısında gevşeklik ve umutsuzluk göstermemeye neden olabilir. Tevhit inancı varlığı ve hayatı Allah'ın bir amaç için yarattığı düşüncesiyle insana varlıkla ilgili bütünlük duygusu verir ve onu anlamsızlıktan kurtarır (Selçuk, 1998: 187). Dünya hayatının imtihan oluşu (Bakara, 2/155, Ali İmran, 3/186, En'am, 6/165), ahiretin varlığ (Bakara, 2/28) ve Allah'ın sonsuz kudret ve adalet sahibi (Enbiya, 21/47) oluşu kişinin bütüncül bir düşünce dünyasına ve anlam haritasına sahip olmasinı sağlar.

Araştırmalar insanların din, Tanrı ve kutsal ile olan bağlllıklarının, hayat amaçlarıyla, anlamlı bir hayat sürmeleriyle ve toplumsal ilişkileriyle ilgili olduğunu ortaya çıkarmıştır. ${ }^{55}$ ABD'de 2000 'den fazla insana dindar olmalarının sebepleri sorulduğunda en çok "din hayatımıza anlam veriyor" yanıtı alınmıştır. ${ }^{56}$

50 Kenneth, I. Pargament "God Help Me: Toward a Theoretical Framework of Coping for the Psychology of Religion", Research in the Social Scientific Study of Religion, 2 (1980), 204-205. Akt. Bahadır, 2011:150.

51 Ferdi Kıraç, Dindarlk Eğilimi, Varoluşsal Kaygı ve Psikolojik Sağlk (Ankara: Ankara Üniversitesi Sosyal Bilimler Enstitüsü, Yüksek Lisans Tezi, 2007), 98; D. Soderstrom- E. Wright "Religion Orientation and Meaning in Life". Journal of Clinical Psychology 33 (1977), 65-68.

52 Carl G. Jung, Keşfedilmemiş Benlik (İstanbul: Barış il han Yayınevi, 2013), 57-67.

53 Prager, Mutluluk Ciddi Bir Sorundur, 24.

54 Murat Yıldız, İnsanların Ölüm Karsısındaki Tutumları Hakkında Yapılan Araştırmaların Değerlendirilmesi (İzmir: 9 Eylül Üniversitesi Sosyal Bilimler Enstitüsü, Yüksek Lisans Tezi, 1994), 35.

55 Kenneth, I. Pargament, "The Psychology of Religion and Spirituailty? Yes Or No", 4.

56 Hülya Güven, Depresyon ve Dindarlk Iliş̧kisi (İstanbul: Marmara Üniversitesi, Sosyal Bilimler Enstitüsü, Yüksek Lisans Tezi, 2008), 58. 
Pargament ve çalışma grubu 586 kişi üzerinde yaptıkları bir araştırmada, dini inançların bazı olayları anlama ve bunlarla başa çıkmada bu süreçlere etki ettiğini ortaya koymuşlardır. ${ }^{57}$

Din bilişsel kontrol ve öfkenin sağaltılması için uygun önerilerde bulunmaktadır. ${ }^{58}$ İslam inancındaki öfke anında ölüm ve ahireti düşünme tavsiyesi bilişsel kontrol için, susmak, hemen cevap vermemek, sabretmek, Allah'a sığınmak, abdest almak şeklindeki tavsiyeler davranışsal beceriler açısından son derece önemli görülmektedir. ${ }^{59}$ Aşkın bir güce sı̆̆ınma, merhameti ve adaleti ondan talep etme yaşanan sıkıntıların ve öfkenin azalmasında ve yok olmasında önemli bir katkı sağlayabilir. ${ }^{60}$

\section{Araştırmanın Yöntemi}

Bilim adamları 20. yüzyılın ortalarından itibaren nitel araştırma yöntemlerine doğru bir değişim ortaya çıktığını ifade etmektedirler. Nicel araştırma yöntemlerinin olayların ve problemlerin ölçülemeyen yönlerini, kültürel yaşantıların birey ve toplum hayatına etkilerini göz ardı etmesi, bazı olayları bütüncül ve doğru olarak açıklayamaması gibi nedenlerle insanların olaylarla ilgili görüşleri, gözlemleri ve analizlerinin de araştırmalara dâhil edilmesi gerektiği sonucuna ulaşılmıştır. ${ }^{61} \mathrm{Bu}$ süreç nitel araştırma yöntemlerinin ortaya çıkmasını sağlamıştır. ${ }^{62}$ İnsanı, insanların olayları yorumlayışını ve insanların iç dünyasını anlamak için, insan faktörünün ön plana çıktığı yöntemler kullanma ihtiyacı nitel araştırmalarının ortaya çıkışına zemin hazırlamıştır. ${ }^{63}$

Ergenler gelişim özellikleri sebebiyle de anlam arayışlarını birçok alanda sürdürmektedirler. İçinde bulundukları kültürel ve dini hayat yaşamlarını etkilemektedir. Bu araştırma nitel çalışmalarda kullanılan "kuram oluşturma" modeline dayanmaktadır. Çalışmada nitel araştırma yöntemlerinde kullanılan yarı yapılandırılmış mülakat tekniği kullanılmıştır.

Nitel araştırmalarda daha az veriyle daha derinlemesine çalışma yapmak konunun daha detaylı anlaşılmasını sağlar. ${ }^{64} \mathrm{Bu}$ araştırma 28 kişilik bir ergen grubu ile yapılmıştır. Türkiye'de TÜíK yaptığı araştırmalarda 16-24 yaş arasını gençlik dönemi

57 Kenneth, I. Pargament vd., “God Help Me (I): Religious Coping Efforts as Preddictors of the Outcomes to Significant Negative Life Events”, American Journal of Community Psychology 18/6 (1990), 813. akt. Talip Küçükcan - Ali Köse, Doğal Âfetler ve Din (Marmara Depremi Üzerine Psiko-Sosyolojik Bir İnceleme) (İstanbul: TDV Yayınları, 2000), 71.

58 Osman Özkan, Öfke Kontrolü ve Dindarlık İlişkisi (Isparta: Süleyman Demirel Üniversitesi, Sosyal Bilimler Enstitüsü, Yüksek Lisans Tezi, 2016).

59 Hüseyin Yeğin, “Öfke Duygusu ve Dini Açıdan Baş Edebilme Yolları”, Din Bilimleri Akademik Araştırma Dergisi 10/2 (2010), 253.

60 Sema Eryücel, Yaşam Olayları ve Olumlu Dini Başa Çıkma (Ankara: Ankara Üniversitesi Sosyal Bilimler Enstitüsü, Doktora Tezi, 2013), 260-265.

61 Fatma Nevra Seggie - Yasemin Bayyurt, Nitel Araştırma Yöntem, Teknik, Analiz ve Yaklaşımları (Ankara: Anı Yayıncılık, 2015), 14; Ali Yıldırım-Hasan Şimşek, Sosyal Bilimlerde Nitel Araştırma Yöntemleri (Ankara: Seçkin Yayıncilık, 2013), 14.

62 Elif Kuş, Nicel- Nitel Araştırma Teknikleri (Ankara: Anı Yayıncılık, 2003), 105.

63 Seggie - Bayyurt, Nitel Araştırma Yöntem, Teknik, Analiz ve Yaklașımları,12.

64 Seggie - Bayyurt, Nitel Araştırma Yöntem, Teknik, Analiz ve Yaklaşımları, 2. 
olarak referans almaktadır. ${ }^{65} \mathrm{Bu}$ nedenle araştırmamızda bu zaman dilimi içerisine giren ergenlerle çalışmayı tercih ettik. Çalışma grubundaki ergenler kendilerini dindar görmekle birlikte farklı yaşam biçimlerine, dünya görüşlerine ve dini yaşantılara sahiptirler.

Ergenlerle mülakat yapılırken amaçlı̈ örnekleme metodu kullanılmıştır. Amaçlı örnekleme metodu örnekleme seçilen kişilerin ya da objelerin, araştırmacının amacına en uygun yanıtı verebilecek kişilerin seçilmesini ifade etmektedir. ${ }^{66}$ Amaçlı örnekleme metodu, çalışılan alanda derinlemesine bilgi ve veri toplamaya ve verilerin açıklanmasına uygun bir metottur. ${ }^{67}$ Nitel yöntemlerde önemli olan örneklemin konuya uygun olmasıdır. Nitel yöntemlerde örneklem grubunun belli bir sayı sınırı yoktur. Örneklem grubunun, bütünü temsil edecek en küçük sayıda alınması esastır. ${ }^{68}$

Nitel araştırmalarda çalışma grubunun farklı demografik özellikler taşıması, farklı özelliklere sahip olması araştırmayı zenginleştiren bir durumdur. ${ }^{69}$ Bu nedenle araştırmamızda farklı cinsiyetten, farklı dindarlık anlayışına, farklı sosyal gruplara ve farklı sosyo-kültürelözelliklere sahip ergenlerle görüşmeye özen gösterilmiştir. Araştırma örnekleminin demografik özelliklerine ilişkin bulgular Tablo 1'de aktarılmıştır.

Tablo 1: Mülakat Grubunun Demografik Özellikleri Değișken

$\mathrm{N}$

\begin{tabular}{lll}
\hline \multirow{2}{*}{ Cinsiyet } & Kız & 14 \\
& Erkek & 14 \\
\hline \multirow{2}{*}{ Eğitim durumu } & Lise & $12(6 \mathrm{kız}, 6$ erkek $)$ \\
& Üniversite & $16(8 \mathrm{kız}, 8$ erkek $)$ \\
\hline \multirow{2}{*}{ STK Mensubiyeti } & Var & 18 \\
& Yok & 10 \\
\hline Toplam & & 28 \\
\hline
\end{tabular}

Araştırmada diğer birçok araştırmada olduğu gibi cinsiyet değişkeni temel değişken olarak tespit edilmiş, hem lise hem de üniversite öğrencileri tespit edilirken kız ve erkek sayılarının eşit olmasına özen gösterilmiştir. Eğitim durumu değişkeninde konunun özelliğine uygun olarak daha çok üniversiteli öğrencilerle görüşme yapilmıştır. Mülakat sürecinde ergenlerin verdikleri cevaplardan bir STK ya da cemaate mensup olup olmadıkları tespit edilmiştir. Bazı konularda STK/cemaat mensubu

65 TÜIK, Türkiye İstatistik Kurumu, Erişim 05 Şubat 2020. http://www.tuik.gov.tr/PreTablo.do?alt_id=1059\#.

66 Aysel Aziz, Sosyal Bilimlerde Araştırma Yöntem ve Teknikleri (İstanbul: Nobel Akademik Yayıncılık, 2014), 55.

67 Seggie - Bayyurt, Nitel Araştırma Yöntem, Teknik, Analizve Yaklaşımları, 28.

68 Aziz, Sosyal Bilimlerde Araştırma Yöntem ve Teknikleri, 56.

69 Seggie - Bayyurt, Nitel Araştırma Yöntem, Teknik, Analiz ve Yaklaşımları, 16. 
olup olmamanın cevaplara etki ettiği tespit edildiği için ayrı bir değişken olarak ele alınmıştır.

Ergenlerde dindarlığın ve dinin anlam arayışına ve anlamsızlığa bağlı sorunlara etkisini ortaya koyan araştırmaların son derece az olması nedeniyle bu araştırmada Kuram Oluşturma Yaklaşımı kullanılmıştır. Bu yaklaşımın amaçlarından biri de yeni kavramsal çerçevelere ulaşmak ve kuramlar geliştirmektir. ${ }^{70}$ Bu sayede literatüre özgün ve önemli bir katkı sağlamak söz konusu olacaktır.

Araştırmada veriler içerik analizine tabii tutulmuştur. İçerik analizi bir metin grubu içerisindeki kelimeleri, kavramları, duygu ve düşüncelerin ifade ediliş şekillerini anlamayı ve anlamlandırmayı ifade eder. ${ }^{71}$

$\mathrm{Bu}$ araştırmada nitel veri analiz programlarından NVivo 12 programı kullanılmıștır. Bu program araștırma verilerinin saklanmasında, düzenlenmesinde ve kodlamalara ulaşmada önemli katkılar sağlamaktadır.

\section{Bulgular ve Değerlendirme: Dindar Ergenlerin Hayatın Anlamı Hakkındaki Düşünceleri}

\subsection{Hayatın Anlamının Ne Olduğu}

Anlama ulaşan kişiler kendi potansiyellerini geliştirir, sorunlarına çözüm bulabilir ve diğerleri ile sağlıklı ilişkiler kurabilirler. Bu sayede yaşamlarını bütünlük içerisinde idame ettirirler. ${ }^{72}$ Yukarıda "Dinin Hayatın Anlamına Etkisi" başlığında konuyla ilgili literatür ayrıntılı olarak paylaşılmış ve tartışılmıştır. Ergenlere "Hayatın anlamı y a da anlamlı bir hayat sizin için ne anlama gelir? Hayatı anlamlı kılan etkenler nelerdir? Örnek vererek açıklayabilir misiniz?" ve "Dini inancınızın hayatınızın anlamına bir etkisi var mıdır? Kendi tecrübeleriniz ışı̆ıında 1-2 örnekle açıklar mısınız?" soruları sorulmuştur. Dini değerlerin hayata anlam katmada oldukça etkili olduğu anlaşılmıştır. Mülakata katılan ergenlerin sorulara verdikleri cevaplar sıklığına göre aşağıdaki temaları ortaya çıkarmıştır:

Tablo 2: Hayatın Anlamı Nedir?

\begin{tabular}{lcc}
\hline Temalar & (n) & (f) \\
\hline Dine uygun yaşantı (Bireysel dindarlık) & 17 & 20 \\
\hline Dini değerler için mücadele etme (Toplumsal dindarlık) & 6 & 6 \\
\hline
\end{tabular}

\subsubsection{Dine Uygun Yaşantı (Bireysel Dindarlık)}

Anlam dünyaya ve hayata bütüncül bir bakış açısı kazandıran ve varlık bütünlüğünü sağlayan en önemli kaynaktır. ${ }^{73}$ Çalışmamıza katılan ergenler de gerek bireysel olarak ibadet etmeye ve iyi bir Müslüman olmaya çalışma açısından gerekse dinin

70 Yıldırım - Şimșek, Sosyal Bilimlerde Nitel Araștırma Yöntemleri, 85.

71 Seggie - Bayyurt, Nitel Araştırma Yöntem, Teknik, Analiz ve Yaklaşımları, 42-54.

72 Bahadır, Hayatın Anlam Kazanmasinda Psiko-sosyal Faktörler ve Din, 226-230.

73 Leon Mckenzie, "The purposes and scope of adult religious education", 7-23. 
ideallerini gerçekleştirme ve yaygınlaştırma açısından dinin yaşamlarına anlam kattığını ifade etmişlerdir.

Liseli bir kız olan KL_1 “İnsanın hayatımın anlamı dediği şey insanın merkezindedir. Insanın fitratının dışına çıkmayıp eeee (duruyor) toparlayamadım. Geriliyor insan bu soruyu düşününce. Bizim merkezimizde Allah olması gerekir. Yani eee dünyada olma, burada olmak çok güzel bir şey ... Bir meslek sahibi olmak, doktor olmak hayatın anlamı değildir. Çünkü biz doktor olmayı kendimiz istediğimiz için değil, Allah yolunda nasıl daha iyi hizmet edebiliriz diye düşünmeliyiz. Eğer ben doktor olarak Allah yoluna hizmet edebileceksem doktor olurum. Eğer benim resmim iyiyse resim çizerek Allah yoluna hizmet edebilirim. Ya da ilahiyat okuyarak ya da psikoloji okuyup insanlarla ilgilenerek. İnsanların uğraş alanı neyse ona göre yaşamalı. İnsan hayatının merkezine Allah'ı oturtursa eğer, hani hayatının anlamı dediği kişiyi yaşamının merkezine oturtur ya onun gibi. Kimisi eşine der hayatımın anlamı, kimisi annesine, kimisi babasına der. Yani kişinin hayatının merkezinde Allah olmalı bence" ifadelerini kullanmıştır. Üniversiteli başka bir erkek katılımcı EÜ_6, dini değerlerin yaşamına anlam kattığını, mesleki ve ailevi hedeflerini de dini değerlere uygun yaşamak amacıyla oluşturduğunu "Hayata bakışım genel itibariyle İslami bir çerçeve içerisinde. Bir nevi İslam benim hayatıma anlam katıyor. Mesela ben Müslüman olmasam, namaz kılmasam, dini önemsemesem, Allah'in varlığı olmasa çok boş yaşayacağım. Ben bunun farkında oluyorum." şeklinde ifade etmiştir. Üniveristeli erkek öğrenci EÜ_1 "Hayatın anlamı dediğimde canlı durup, diri durmayı anlıyorum. Ama bizim anladığımı anlamda hangi kaynaktan beslenerek hayatımızın anlamın oluşturmamı gerektiğini düşündüğünüzde hayatın anlamının en iyi Kur'an-ı Kerim'den yola çıkarak oluşturulabileceğini görebiliyoruz. Ben şöyle tanımlıyorum: En çok Kur'an'ın anlamın kim bulduysa hayatın anlamın en çok o kişi bulmuştur." ifadesini kullanmıştır. Benzer ifadeleri 17 öğrenci 20 kez kullanmıştır.

\subsubsection{Dini Değerler İçin Mücadele Etme (Toplumsal Dindarlık)}

Bazı katılımcılar dini sadece bireysel ibadetler ve vicdani bir sorumluluk olarak görmemekte, dini değerlerin insan ve toplum hayatında yaygınlaşmasının önemine vurgu yapmaktadırlar. Katılımcılar yeryüzündeki kötülüklerle dini referanslar merkeze alınarak mücadele edilmedikçe daha iyi bir dünyanın mümkün olamayacağını, gençlerin boş işlerle ya da dünyevi hedefler ile çok uğraştıklarını, insanın gerek mesleği ile gerekse sahip olduğu diğer olanaklar ile dini ilkeleri diğer insanlara tebliğ etmesi gerektiğini ifade etmişlerdir. Bu ifadeler "dini değerler için mücadele etme" teması altında ele alınmıştır. Dini bu şekilde gören anlayışlar farklı toplumlarda ve farklı dini topluluklarda da bulunmaktadır. Bazı kişilerin sorulara verdikleri cevaplar aşağıdadır:

Üniversiteli kız öğrenci KL_2 hayatın anlamının insanlara dini değerlerin anlatılması olduğunu şu şekilde ifade etmiştir. “Anlamlı hayat öncelikle bir şeye bağlı olunan bir hayattır. Benim hayatımın merkezinde Allah inancının olması gibi. Tabii ki Müslüman olan insanlar da var ama herkes hayatına tam olarak yansıtmaya çalışmıyor. Burada bir ayrıma gidecek olursak benim için, inandiğım değerlere göre yaşamak ve bu değerleri yaşatmak için çabalamak benim için anlamlı bir hayattır. Çünkü iyi insan olduğun zaman hani tamam ne 
olacak sonra diyorsun ama başkalarının da iyi olması için uğraşmak bitmeyen bir süreç. Ben şu an bir okula staja gidiyorum. Öğrenciler birçok yanlışın içine girmişler. Yalan söylüyorlar, sevgili muhabbeti yapıyorlar falan. Bu çocuklara doğruları anlattı̆̆m zaman şöyle düşünüyorum. Bu dünyada benim iy anlamda yaptığım şeyler var. İnsanlara faydah olabiliyorum. Böyle olunca da kendimin Allah nezdinde daha değerli olduğunu hissediyorum belki de." Üniversiteli kız öğrenci KÜ_3, anlamlı bir hayatın ancak Allah inancının ve Allah'ın koyduğu hedeflerin yaygınlaşması ile mümkün olacağını vurgulamıştır: "Hayatın anlamı Allah'in varlı̆̆na olan inancım, Allah'in bizden istediği şeyleri yapıyor olmak, dertli olmak belki de. Mücadele edebiliyor olmak, koşturuyor olmak, insanları önemsemek. Bir yerlerde birileri ölüyorken sessizce oturmak değil.” Mimarlık bölümü öğrencisi EÜ_3 “İnsanin dünyaya firlatılıp atıldığın düşünmüyorum. İnsanin bu dünyada varoluşunun bir amacı olduğunu, düşünüyorum ve bu amaç doğrultusunda hareket etmesi gerektiği kanısındayım. Temel olarak bu anlamı anlamlandırmaya çalışıyorum. İnsan Allah'in bu dünyaya gönderdiği halifesidir ve insanın bundan dolayı bir takım görev ve sorumlulukları vardır. Bu görev ve sorumluluklar insanı anlamlı ve değerli kılıyor. Böylece hayatın anlamlı kılabileceğini düşünüyorum." demiştir.

\subsection{Anlamlı Hayat Yaşayan Kişilerin Özellikleri}

Katılımcıların anlamlı hayat ile ilgili düşüncelerini hangi tür pratiklerle özdeş gördüklerini anlamak amacıyla "Çevrenizde anlamlı bir hayat yaşayan bir kişi (yaşı fark etmez) var mıdır? Varsa o kişinin anlamlı bir hayat yaşadığın nereden/nasıl çıkarıyorsunuz? Bu kişi hangi özelliklere sahip? Açıklar mısınız?" ve "Hayatınızda model aldığınız bir kişi var mıdır? Bu kişi hangi özelliklere sahip? Açıklar mısınız?" sorusu sorulmuştur. Mülakata katılan ergenlerin anlamlı hayat yaşayan örneklere ilişkin verdikleri cevaplar Tablo 3'te aktarılmıştır:

Tablo 3: Anlamlı Hayat Yaşayan Örnekler

\begin{tabular}{lcc}
\hline Kategoriler ve Temalar & (n) & (f) \\
\hline Yaşayan örnekler & & \\
\hline$-\quad$ Dini gruplardaki örnekler & 21 & 32 \\
\hline$-\quad$ Ailedeki örnekler & 10 & 12 \\
\hline$-\quad$ Sosyal çevreden örnekler & 8 & 9 \\
\hline Tarihsel Karakterler & & \\
\hline - $\quad$ Hz Muhammed & 8 & 8 \\
\hline - $\quad$ Farklı örnekleri (Peygamberler, âlimler, şehitler vb.) birleştirme & 20 & 22 \\
\hline Yaşayan ideal bir model yok & 6 & 6 \\
\hline
\end{tabular}

Gençler değer verdiği, hayranlık duyduğu kişilerle özdeşim kurar ve onların davranışlarını benimser (Yörükoğlu, 2000: 102-105).

Tablodan da anlaşılacağı üzere anlamlı hayat yaşayan örneklere 21 öğrenci 32 kez dini gruplarından örnekler vermiştir. Aynı zamanda 28 öğrenci peygamberler, âlimler ve şehitler gibi dindar kişilerin anlamlı yaşadığını ifade etmiştir. Temayla ilgili bazı ifadeler aşağıdadır: 
"Hayatımı anlamlı kılmada bana en çok etkili olan şeyi şu an içinde bulunduğum vakıf ya da arkadaşlarım sağlıor. Geçen yıl yaşadığım sıkıntıyı benim gibi düşünen kaygılarımızın ortak olduğunu düşündüğüum E.... abla ile görüşerek çözmeye çalş̧ım. Bu yıl da yine oda arkadaşım S..... ile bu tür konuları konuşuyorum. Bana çok iyi geliyor, beni rahatlatıyor." (KÜ_2) "İçinde bulunduğum cemaat açısından düşünecek olursak evet anlamlı bir hayat yaşıyorlar. Insanların sorunlarını dert etme, bir mücadele içerisine girme, bir takım sorumluluklarn alma fikri onlarda var. Cemaatim ve ister istemez mesleğim gereği içerisinde koşuşturduğum hastane ortamı arasinda çok ciddi fark var. Az önce de anlamsız bir hayat yaşıyorlar derken daha çok hastane ortamındaki arkadaşlarımı kastetmiştim. Dindarlık algımın değiştiğini düşünüyorum. Sizin "Bilgi değil bilinç güçtür." ifadeniz vardı. Bu benim için çok anlaml." (KÜ_3)

"Anlaml yaşamaya çalışan kişiler elbette var. Dernek camiasına baktığımda, değerli hocalarımıza baktığımda, onların hayatı, yaptıkları anlamlı şeyler geliyor aklıma." (KÜ_5)

"Kendi çevremde ve mensup olduğum cemaatte kimse kendisini merkeze almıyor, hep başkasını düşünme sorumluluğu var. Bu bir erdemdir. Bundan dolayı anlamlı olduğunu düşünüyorum. Benim içinde bulunduğum çevrede fedakârlık ya da diğerkâmlık olduğunu düşünüyorum. Tabii sorunlar olsa da herkes aynı olmasa da içinde bulunduğum cemaatteki gençlerin topluma göre daha anlamlı bir hayat sürdüklerini düşünüyorum. Örneğin herkesin bir sorumluluk alanı var. Herkes yetkin olduğu alana göre bir sorumluluk altyor." (EÜ_4)

Verilen cevaplar ergenlerin dinin, pratikte anlamlı hayat yaşamaya olan olumlu etkisini göstermesi açısından anlamlıdır.

Katılımcıların anlamlı yaşayan kişiler ile ilgili olarak verdikleri cevapların bazıları doğrudan dini değerler ile ilgilidir. Bu cevaplar "Dindar kişiliközellikleri" olarak temalaştırılmıştır. Diğer cevaplar ise kişilerin bireysel ve sosyal özellikleri ile ilgilidir. Bu cevaplar da "Bireysel kişilik özellikleri” olarak temalaştırılmıştır. Katılımcı ergenler anlamlı hayat yaşadığına inandıkları kişilerle ilgili olarak 40 kez dindar kişilik özelliklerini, 5 kez de bireysel kişilik özelliklerini ifade etmişlerdir. Cevaplardan elde edilen bulgular Tablo 4'te aktarılmıştır.

Tablo 4: Anlaml Hayat Yaşayan Kişilerin Özellikleri

\begin{tabular}{|l|c|c|}
\hline \multicolumn{1}{|l|}{ Temalar } & (n) kişi & (f) sayı \\
\hline Dindar kişilik özellikleri & & \\
\hline - Dini değerleri yaymak için mücadele etmeleri & 16 & 23 \\
\hline Dine uygun, erdemli bir hayat yaşamaları & 11 & 12 \\
\hline - $\quad$ Evrensel bir bilinç ve farkındalığa sahip olmaları & 5 & 5 \\
\hline Bireysel kişilik özellikleri & 4 & 5 \\
\hline
\end{tabular}


Dini yaşam ve dindarlık hayatın sadece sınırlı bir alanında geçerli olan, sadece içsel vicdani duygularla ilgili olan bir duygu değildir. Dindarlık hayatın tüm alanlarını kuşatan bir duygudur. Bu nedenle dindarlık insan için hayatın anlamını ilgilendiren anahtar kavramlardan biridir. Frankl'e göre dindarlar daha derin bir sorumluluk bilincine ve daha derin bir Tanrı tecrübesine sahip oldukları için daha güçlü bir anlamlılığa sahiptirler. ${ }^{74}$

Katılımcıların dindar kişilik özellikleri olarak en sık vurguladığı nokta anlamlı yaşayan kişilerin dini değerlerin yaygınlaşması için fedakârlık yapmaları ve gayret göstermeleridir. Üniversiteli erkek öğrenci EÜ_1 katıldığıSTK'daki gençlerin diğer insanlara ulaşmak için yaptıkları faaliyetleri ve Hz. Muhammed'in mücadeleci yönünü şöyle ifade etmektedir: "Bu insanlar kendi dışındaki insanların sorunları ile ilgileniyorlar, dünyevi çıkarların peşinde koşan insanların sorunlarıla ilgileniyorlar, bunlar için çaba veriyorlar, mücadele ediyorlar, araştırıyorlar ve sorguluyorlar. Programlar yapıyorlar, dergi çıkarıyorlar, internet sitesi idare ediyorlar. İşte zamanların feda ediyorlar, gerekirse paralarını feda ediyorlar, canla başla Allah yolunda gayret ediyorlar. Böyle anlamlı gördüğüm çok insan var Allah'a şükürler olsun. Ayrıca Hz. Muhammed'in hayatını okuduğum zaman mücadelesinden, gayretinden hep çok etkilenirim. Onun sadece merhametli, sevgi dolu değil de savaşçı ve mücadele ruhu da beni çok etkiliyor. Çünkü bize daha çok eksik gösteriliyor Hz. Muhammed. Isşte hoşgörü peygamberi diyorlar sadece böyle değil de zulme karşı boyun eğmeyen, zalime karşı mücadele eden, Allah rızası için yaşamay a çalışan biri olması beni en çok etkileyen yönlerinden biri.” Üniversiteli kız öğrenci, cemaat çevresindeki arkadaşlarının ve hocalarının Allah rızası için yaşadıklarını ve diğer insanların da anlamlı bir hayat yaşaması için mücadele ettiklerini ifade etmiştir. "Bu insanlarm hayatta iyinin ve kötünün farkında olduklarını, hayatın bir mücadele olduğunu, imtihanın olduğunu fark ettiklerini ve bunun için çabaladıklarını görüyorum. Ve bu anlamda da Allah'ın rızasına göre yaşamaya çalıştıklarını, ortaya bir şey koyduklarını görüyorum. Bir kere insanlarla uğraşıyor olmaları, insanların gönüllerine dokunmaya çalışmaları, başkalarının da anlamlı bir hayat yaşaması için çalışmaları, dertlerinin olması, uykusuz gecelerinin olması, kitap yazıyor, yazı yazıyor olmaları bunu gösteriyor. Gerçekten yazdıkları yazılardan çok etkilendiğim insanlar var. Bazılarının bir şey demesine de gerekyok, o ortamda bulunmaları bileyetiyor bana." (KÜ_3).

Dindar kişilik özellikleri temasında öne çıkan diğer tema, anlamlı hayat yaşayan kişilerin "Dine uygun, erdemli bir yaşam sürmeleri”dir. Katılımcılar bu temada dini duygulara sahip olmayı, dini konularda fedakârlık yapmayı, hem ahiretini hem de bireysel geleceğini birlikte yürütebilmeyi, çabaların sonucunu Allah'tan ummanınönemini anlamlı bir hayatın ögeleri olarak dile getirmişlerdir. Bazı katılımcı ifadeleri aşağidadır:

“Ama etrafimda böyle insanların var olduğunu düşünüyorum ve bu insanların neden anlamlı bir hayat yaşadıkların düşünmemin sebebi de şey. Biraz daha, şöyle diyeyim fedakârlkkları. Yani mesela bazıları kendi okulu var, işi gücü var ama mesela gidiyor liselerdeki öğrencilerle falan etkinlikler yaptyorlar. Mesela bu benim

74 Abdülkerim Bahadır, "Hayatın Anlam Kazanmasında Psiko-sosyal Faktörler ve Din”, 216. 
için büyük bir fedakârllk. Ya da mesela kermeslerde mesela çok görüyorum, çokfedakârlk yapan insanları görüyorum, kadınları görüyorum mesela." (KÜ_8)

"Hem mesleğini yapıyor hem de dini açıdan en güzelini yaşıyor. Onun hakkında hiç kimse kötü bir şey söylemez. Dini açıdan da tam bir insan olduğunu düşünüyorum. Hem mesleği elinde hem de inancını yaşıyor. Herkes de onu çok iyi bir insan olarak biliyor. Bence böyle bir hayat çok anlamlı bir hayat. Onu asla isyan ederken görmedik." (KL_3)

Katılımcıların öne çıkardığı diğer bir tema, dinin hayata ve dünyaya dair entelektüel çerçevesinin önemini vurgulamaları olmuşlardır. "Evrensel bir bilinç ve farkındalığa sahip olmaları" olarak adlandırılan bu temada ergenler, dini düşüncenin derinliğine ve üstünlüğüne vurgu yapmışlardır. Bir cemaat/STK mensubu olduğunu ifade eden üniversiteli erkek katılımcı EÜ_1, bulunduğu cemaatin temel özelliğinin hayata ve olaylara sorgulayıcı ve eleştirel bir bakış ile yaklaşmak olduğunu ifade etmiştir: "Bulunduğum cemaatte her şey sorgulanabiliyor, daha çok eleştirel düşünmeye yöneliş var ki bugün en çok ihtiyaç duyduğumuz şey eleştirel düşünmedir. Bulunduğum cemaatin eksikliği de olabilir tabii ama tutarlı olmaya çalıştıkları ve hayatı sorguladıkları için daha anlamlı bir hayat yaşadıklarını düşünüyorum gençlerin. Buradan diğer cemaatleri küçümsediğim kötülediğim çıkarılmamalı tabii. Daha önce farklı cemaatlerin sohbetlerinde de bulundum ama hiç bu şekilde böyle bir bakış açısı, bu şekilde bir eleştirel düşünceye şahit olmadım. Siyasi bir akıl ya da tüm dünyayı okuma gibi şeyler görmedim. Bir yapı evrenselliğini kaybettiği zaman hiçbir işe yaramıyor. Kendi köyüne kapanıyor yani."

\subsection{Toplumdaki Gençlerin Yaşantısının Anlamlılık Düzeyi Hakkındaki Düşünceleri}

Ergenlerin içinde yaşadıkları ve benliklerini inşa ettikleri toplum ve gençler hakkındaki düşüncelerini anlamak amacıyla "Arkadaş çevreniz anlamlı bir hayat mu, anlamsız bir hayat mı yaşıyorlar? Nedenini açıklar mısınız?" ve "Etrafinızda boş bir hayat yaşayan kişiler var mıdır? Boş hayat yaşadıkları sonucuna nasıl ulaşıyorsunuz?" soruları sorulmuştur. Mülakata katılan ergenlerin cevaplarından elde edilen temalar sıklığına göre şu şekilde oluşmuştur:

Tablo 5: Toplumdaki Gençlerin Yaşantısının Anlamlılık Düzeyi Hakkındaki Düşünceleri

\begin{tabular}{|c|c|c|c|}
\hline & Temalar & (n) & (f) \\
\hline \multicolumn{4}{|c|}{ Hayatlarının Anlamsız Olduğu } \\
\hline \multirow{3}{*}{ 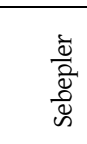 } & Bireysel bir yaşam sürmeleri & 22 & 23 \\
\hline & Kariyer ve meslek odaklı olmaları & 10 & 11 \\
\hline & Dini ve değerleri önemsememeleri & 10 & 10 \\
\hline \multicolumn{2}{|c|}{ Anlamlı bir hayat yaşadıkları } & 1 & 1 \\
\hline
\end{tabular}

\subsubsection{Hayatlarının Anlamsız Olduğu}

Toplumdaki gençlerin hayatlarının anlamsız olduğunu belirten katılımcıların en sık ifade ettikleri tema "bireysel bir yaşam sürmeleri” olmuştur. Bu temada gençlerin faydasız, geçici ve boş işler ile ilgilendikleri, sadece eğlenme amaçlı yaşadıkları, 
derslerini ve parayı çok fazla önemsedikleri, sosyal medya ve sosyal ortam bağımlısı oldukları sıklıkla dile getirilmiştir. Modern hayatın temel dinamikleri olan hedonizme, konformizme ve maceraya değer veren kişilerde anlam duygusunun düşük olduğu görülmüştür. ${ }^{75}$ Ekonomik gelişmişlik, konfor ve olanaklara sahip olma ergenlere daha anlamlı bir hayat sağlamadığı gibi anlam duygusunun azalmasına da neden olmuştur. ${ }^{76}$ Liseli erkek katılımc1 "Yani hocam bi kere şu zamanki gençlikte bi umursamamazlık, tamamen laubali bir yaşam var. Bayağı takılıyorlar yani ben de bir genç olarak yaşlılardan fazla gençleri eleştiriyorum. Karı kızla takıllyor, muhabbetler seviyesiz, düny alık olmuş hayatlar, İslami kaygıları asla yok. Şahsen ben onlardan farklı olarak biriyle oturup konuştuğum zaman kim olursa olsun kız veya erkek olsun, oturuyorsam konuşuyorsak İslami konularda konuşmamı lazım, gerekli değerli konular konuşmamız lazım, boş konuşmamam lazım. Boşa harcayacak vaktim olduğunu düşünmüyorum. Gençler zamanı boşa harcıyor, boş muhabbetlerle vakitlerini çar çur ediyor. Şu an dünyada yaşıyorsak, dünyanın öbür tarafinda olan, ezilen insanların sorunları için neler yapmamı gerekir, kişilerin dertleri ve kendi dertlerimiz üzerine konuşmamı lazım ama genelde gençlerde gördüğüm ve bundan dolayı da bi çokgençle anlaşmamamin sebebi bu boş lakayt seviyesiz tavirlardır." (EL_1) demiştir. Üniversiteli erkek katılımcı EÜ_1 ergenlerin yaşadıkları boşluğu ve farkındalık eksikliğini "Gençlerin anlamlı bir hayat yaşayıp yaşamadıklarına gelince ben gençlerin bir hayat yaşayı yaşamadıklarını ya da anlamlı bir hayatları olup olmadıklarının farkında olup olmadıkları konusunda ciddi anlamda şüphelerim var." ifadesiyle görüşlerini belirtmiştir.

Kariyer ve meslek odaklı olmak katılımclara göre gençlerin anlamsız bir hayat yaşadıklarının ikinci önemli göstergesidir. Bu temada ergenler parayı çok önemsemenin, kariyeri hayatın merkezi olarak görmenin, daha üst amaçlara sahip olamamanın anlamsız bir hayatın göstergesi olduğunu ifade etmişlerdir. Üniversiteli kız öğrenci KÜ_3 "Gençlere baktığımda anlamsız bir hayat yaşadıklarını düşünüyorum. Mesela sadece doktor olmaky a da para kazanıyor olmak onlar için yeterli olabiliyor. Ya da ev iş arasında gidip gelmeleri, tek bir sayfa kitap okumuyor olmalar, herhangi bir zihinsel sürece girmiyor olmaları, çevrelerindeki insanları düşünmüyor ve önemsemiyor olmaları... Mesela doktor olmakörnek bir profil gibi görünebiliyor ama hastalarını bile sahiplenmeyebiliyorlar." ifadesini kullanmiştır.

Ergenlerin anlamsız bir yaşam sürdüklerine ilişkin bir diğer tema "ergenlerin dini ve değerleri önemsememeleri” olarak karşımıza çıkmıştır. Katılımcılar dini, hayatlarına anlam katan bir değer olarak gördükleri için toplumdaki gençlerin bu değerlerden ve dini inançtan uzak olmalarını anlamsız yaşadıklarının işareti olarak gördüklerini ifade etmişlerdir. Üniversite öğrencisi EÜ_2 “Ama diğer türlü Müslüman bir toplumda yaşıyorsun ve Müslümanların insana getirdiği bir şeyler var. Buna rağmen bu değerleri aykırı bir hayat yaşıyorsun. İște böyle bir hayat anlamsız bir hayat oluyor." ifadesini kullanmıştır. 11. sınıf öğrencisi erkek bir katılımcı arkadaş çevresinin anlamlı

\footnotetext{
75 James, E Crandall - Roger, D Rasmussen, “Purpose in Life As Related To Specific Values”, Journal of Clinical Psychology 31/3 (1975), 483-485.

76 Kıraç, Dindarlı Eğilimi, Varoluşsal Kaygı ve Psikolojik Sağ lık, 131.
} 
hayat yaşadığını ifade etmiştir. Bu öğrenci toplumdaki gençlerin anlamlı hayat yaşaması ile ilgili cümle kurmamıştır.

\section{Sonuç ve Öneriler}

$\mathrm{Bu}$ araştırma dinin ergenlerin anlam arayışlarına ve anlamlı bir hayat yaşamalarına etkilerinin neler olduğunu ortaya koymayı amaçlamıştır. Dinin ergenler üzerindeki etkisini inceleyen çalışmalar olmadan ergen davranışlarını bütünlük içerisinde ve sağlıklı bir şekilde anlamak mümkün olmayacaktır. Anlam arayışı da bu açıdan Pozitif Psikolojinin temel çalışma alanlarından biridir.

Ergenlerin hayata bütüncül bir şekilde bakmalarını sağlayacak, varoluşlarını anlamlandıracak temel bir anlam ve değerler sistemine ihtiyacı vardır. Tillich'in de ifade ettiği gibi gençler "bütün anlamlara anlam veren anlam"1 kaybetmiştir. Dini değerler ergenler için iyi bir anlam sistemi alternatifi olabilir. Anlam arayışı fitri bir süreçtir. 0 halde anlama ulaşmak, fitrata ve yaradılışa uygun bir yaşam sürmekle mümkündür.

Ergenlerin çoğu inançlarının kişiliklerinde önemli olduğunu belirtmiştir. Bazı ergenler kendilerini dini inançlarını yaşamaya çalıștıklarını ifade eden kavramlarla tanımlamışlardır. Bireysel dindarlık olarak tanımlanabilecek bu yaklaşıma karşın, bazı ergenler kendilerini dini değerleri yüceltmek misyonu ile tanımlamışlardır. Bu tanımlama ile katılımcılar dinin toplumsal, kültürel ve siyasal hayatla ilgili idealleri olduğunu belirtmişlerdir. Bu şekilde tanımlayanların çoğu üniversite öğrencileridir. Daha çok lise öğrencisi olan bazı katılımcılar anlam arayışı içerisinde olduklarını ifade etmişlerdir. Bu sonuç ergenlik döneminin kimlik bulma dönemi olduğu ile ilgili literatür ile örtüşmektedir.

Katılımcıların büyük çoğunluğu hayatın anlamını dini değerler ve idealler ile ilişkilendirmiştir. Bulgular dinin hayata anlam kattığını gösteren araştırma sonuçları ile paraleldir. Bazı ergenler hayatın anlamını iyi bir aileye sahip olmak olarak ifade etmişlerdir. Bu sonuç ergenlik döneminde ailenin koruyucu ve destekleyici sonuçlarını göstermesi açısından önemlidir. Çoğunluğu lise öğrencisi olan bir grup öğrenci, insanlık ve ülkesi için faydalı bir birey olmayı hayatın anlamı olarak görmüşlerdir. Bireysel bir yaşam sürmeyi, salt kişisel hedefleri için uğraşmayı hayatın anlamı olarak gören bir katılımcı olmamıştır. Sonuç dindarlığın gençleri benmerkezcilikten kurtardığını işaret etmesi açısından önemlidir.

Mülakat katılan ergenlerin biri hariç tümü gençlerin çoğunluğunun anlamsız bir hayat yaşadığını ifade etmiştir. Bir katılımcı bu konuda ifadede bulunmamıştır. Gençlerin bireysel, eğlence merkezli bir yaşam sürmeleri, kariyer ve meslek odaklı olmaları, dini ve değerleri önemsememeleri anlamsız yaşadıklarının belirtileri olarak yorumlanmıştır. Ergenler anlamlı hayat yaşayan özellikleri olarak en çok dindar kişilik özelliklerini saymışlardır. Buna göre dini değerleri yaygınlaştırmak için çaba göstermek anlamlı bir hayatın en önemli işareti olarak ifade edilmiştir. Bununla birlikte ibadetleri yerine getirmek, dini ve ahlaki kurallara uygun yaşamak ta anlamlı hayatın belirtileri olarak yorumlanmıştır. 
Katılımcıların yarısından fazlası cemaat, dernek vb. bir STK'ya mensup olduğunu ifade etmiştir. Bu kişiler anlamlı hayat yaşayan kişiler olarak en çok dini gruplarından örnekler vermişlerdir. Dini grupların hayatın anlamını bulmada ve anlamsızlık yaşamamada ergenlere katkı sağladığı anlaşılmıştır.

Kur’an-1 Kerim “Onlar inanan ve Allah'i anmakla gönülleri huzur bulan kimselerdir. İyi bilin ki gönüller, ancak Allah'ı anmakla huzur bulur” (Râ'd, 13/28) ayeti ile bunalım, depresyon, kaygı ve anlamsızlık yaşayan gençliğe mutlu ve anlamlı bir hayatın ilahi ilkeler ile mümkün olduğunu söylemiştir. Psikoloji ruhun sağlığıyla, din ruhun kurtuluşuyla ilgilenir. Sağlıksız bir ruhla kurtuluşa erilemeyeceği gibi, kurtuluşa götürmeyen bir sağlıklılık ta anlamsız olmaktadır. O halde din ve psikoloji ele ele verip gençliği huzur, mutluluk ve anlam dolu bir hayata ulaştırabilirler.

\section{Öneriler}

Araştırmanın gençlerde dinin hayatın anlamına olumlu katkılar sağladığı, anlam arayışı içerisinde olan gençlere alternatif bir anlam sistemi sunabileceği ve anlamsızlığa bağlı sorunlara karşı koruyucu olduğu görülmüştür. Bu sonuçlar 1şığında aşağıdaki önerilerde bulunmak mümkündür.

Gençlik dönemini olumlu bir bakış açısıyla ele alan araştırma ve çalışmaların artması faydalı olacaktır.

Eğitim sisteminin sınavlar merkezli yürümesinin ve kariyer odaklı, bireysel yaşam tarzının gençleri olumsuz etkilediği anlaşılmaktadır. Kimlik gelişimi dönemindeki gençlerin sağlıklı bir hayat felsefesi oluşturmalarında dini duygu ve değerlerin katkılarından yararlanılabilir. Özellikle ortaöğretim sisteminde bu bakış açısını sağlayacak dersler, projeler ve eğitim içerikleri belirlenebilir. Anlam, anlam arayışı ve hayatın anlamı ile ilgili konulara eğitim öğretim müfredatında disiplinlerarası bir yaklaşım ile daha çok yer ayrılabilir.

Dinin ve dindarlığın hayatın anlamına olan etkisi ile ilgili psiko-eğitim programları oluşturulabilir.

Eğitim öğretim süreçlerinde kazanımların belirlenmesinde dini ve ahlaki gelişim ile ilgili kazanımların müfredatta yok denecek kadar az olduğu görülmüştür. Eğitim politikaları belirlenirken dinin gençlere olan katkılarından faydalanılabilir.

Bazı yaşantıların gençlik döneminde dini şüphe ve tereddütlere neden olduğu bilinmektedir. Bu konularla ilgili Milli Eğitim, Gençlik ve Spor, Çalışma ve Aile Bakanlığı ile Diyanet İşleri Başkanlığı gibi kurumların konuyu çok boyutlu olarak, eşgüdümlü bir şekilde ele alması anlamlı yaşayan bir gençlik kitlesinin ortaya çıkması için faydalı olacaktır.

Aile hayatının öneminin birçok tema ve alt temada ön plana çıktığı görülmüştür. Ülkemizdeki artan boşanma ve azalan evlenme oranları gençlerin evlilik hayatından endişe duymalarına neden olmaktadır. Aile değerlerinin ve aile yapısının korunmasına yönelik sosyal, kültürel, sanatsal ve ekonomik çalışmaların yapılması önem taşımaktadır. 
Dinin; gençlerin mutluluğuna, güven duygusuna, umutlu olmasına ve değerlere dayalı erdemli bir hayat sürmesine olan katkılarıyla ilgili nicel ve nitel araştırmaların yapılması literatüre katkı sağlayabilir. Böylece daha geniş ve çok yönlü sonuçlar elde etmek ve sonuçları genellemek mümkün olacaktır.

İslam inancının Türkiye toplumundaki gençlere olan çok boyutlu etkilerini ve katkılarını ortaya koymak amacıyla yeni ölçme ve değerlendirme araçları geliştirilebilir.

Etik Beyan / Ethical Statement

Yazar / Author
Bu çalışmanın hazırlanma sürecinde bilimsel ve etik ilkelere uyulduğu ve yararlanılan tüm çalışmaların kaynakçada belirtildiği beyan olunur/It is declared that scientific and ethical principles have been followed while carrying out and writing this study and that all the sources used have been properly cited.

Yasin Kuruçay

\section{Kaynakça}

Adler, Alfred. Yaşamanın Anlam ve Amacı. çev. Kamuran Şipal. İstanbul: Say Yayınevi, 1998.

Allport, Gordon W. Birey ve Dini. çev. Bilal Sambur. Ankara: Elis Yayınevi, 2004.

Aziz, Aysel. Sosyal Bilimlerde Araștrrma Yöntem ve Teknikleri. İstanbul: Nobel Akademik Yayıncıllk, 8. Bask1, 2014.

Bahadır, Abdülkerim. Hayatın Anlam Kazanmasında Psiko-sosyal Faktörler ve Din. Bursa: Uludağ Üniversitesi Sosyal Bilimler Enstitüsü, Doktora Tezi, 1999. https://doi.org/10.17218/hititsosbil.369391

Bahadır, Abdülkerim. "Hayatın Anlam Kazanmasında Psiko-sosyal Faktörler ve Din”. Selçuk Üniversitesi Sosyal Bilimler Enstitüsü Dergisi 6 (2000), 85-126. https://doi.org/10.29029/busbed. 581022

Baier, Kurt. The Meaning of Life. ed. E. D. Klemke-Steven Cahn. Oxford: Oxford University Press, 1971.

Baumeister, Roy F-Michael J. MacKenzie, "Meaning in Life: Nature, Needs, and Myths". in Meaning in Positive and Existential Psychology. (ed.), Batthyany A.-P. Russo Netzer. New York: Springer Press, 1991, 25-37. doi: 10.1007/978-1-4939-0308-5_2

Bilge, Emine Zehra. Liseli Gençlerde İç ve Dış Güdümlü Dindarlı ve L̇yilik Algıları. Eskişehir: Osmangazi Üniveristesi, Yüksek Lisans Tezi, 2013. https://doi.org/10.17494/ogusbd. 763650

Bilgin, Vecdi. “Popüler Kültür ve Din: Dindarlığın Değişen Yüzü”. Uludağ Üniversitesi İlahiyat Fakültesi Dergisi 12/1 (2003), 193-214.

Chamberlain, Kerry - Sheryl Zika. "Religiosity, Life Meaning and Wellbeing: Some Relationships in a Sample of Women”. Journal for The Scientific Study of Religion 27/3 (Sep.1988), 411-420. https://doi.org/10.2307/1387379 
Crandall, James, E. - Rasmussen, Roger, D. "Purpose in life as related to specific values". Journal of Clinical Psychology 31 (1975), 483-485.

Eryücel, Sema. Yaşam Olayları ve Olumlu Dini Başa Çıkma. Ankara: Ankara Üniversitesi Sosyal Bilimler Enstitüsü, Doktora Tezi, 2013. https://doi.org/10.9775/kausbed.2018.042

Fowler, James, W. Stages of Faith, The Psychology of Human Development and Quest for Meaning. San Francisco, Harper and Row, 1981.

Frankl, Viktor E. "The Feeling Of Meeninglessness: A Challange to Psychotherapy”. Journal of Psychoanalysis 32 (1972), 85-89.

Frankl, Viktor E. Duyulmayan Anlam Çığlğı çev. Selçuk Budak. Ankara: Öteki Yayınevi, 1999.

Frankl, Viktor E. İnsanın Anlam Arayışı. İstanbul: Okuyan Us Yayınevi, 2016.

Frankl, Victor E. “What is meant by meaning”. Journal of Existentialism 7/25 (1966), 21-28.

Guenon, Rene. Modern Dünyanın Bunalımı. çev. Mahmut Kanık. İstanbul: Hece Yayınevi 2005.

Gürses, İbrahim. Dindarlk ve Kişilik. Bursa: Emin Yayınevi, 2010.

Güven, Hülya. Depresyon ve Dindarlk İlişkisi. İstanbul: Marmara Üniversitesi Sosyal Bilimler Enstitüsü, Yüksek Lisans Tezi, 2008.

Hicks, Joshua - Laura A King. "Meaning in life and seeing the big picture: Positive affect and global focus". Cognition and Emotion 21/7 (November 2007), 1577-1584. https://doi.org/ 10.1080/026 99930701347304

Hökelekli, Hayati. Din Psikolojisi. Ankara: TDV Yayınları 2013.

Hökelekli, Hayati. Din Psikolojisine Giriş. İstanbul: Dem Yayınları, 2012.

Hökelekli, Hayati. Gençlik, Din ve Değerler Psikolojisi. İstanbul: Dem Yayınları, 2006.

Hökelekli, Hayati. “Ergenlik Çağı Davranışlarına Din Eğitiminin Etkisi”. Uludağ Üniversitesi İlahiyat Fakültesi Dergisi 1/1 (1986), 35-51.

Jung, Carl G. Keşfedilmemiş Benlik. İstanbul: Barıș ìlhan Yayınevi 2013.

Kıraç, Ferdi. Dindarlı Eğilimi, Varoluşsal Kaygı ve Psikolojik Sağlık. Ankara: Ankara Üniversitesi Sosyal Bilimler Enstitüsü, Yüksek Lisans Tezi, 2007.

Kızılırmak, Özlem. Genç Yetişkinlerde Yaşamda Anlamın Maneviyat ve Kişilik Özellikleri Açısından İncelenmesi. Ankara: Gazi Üniveristesi, Eğitim Bilimleri Enstitüsü, Yüksek Lisans Tezi, 2015. https://doi.org/10.30520/tjsosci.571198

Koç, Mustafa. "Dindarlık İle Benlik Saygısı Arasındaki İlişki: Yetişkinler Üzerine Ampirik Bir Araştırma". Uludağ Üniversitesi İlahiyat Fakültesi Dergisi 18/1 (2009), 473-493. https://doi. org/10.34 085/buifd.611302

Köknel, Özcan. Cumhuriyet Gençliği ve Sorunları. İstanbul: Cem Yayınevi, 1981.

Kranz, Walter. Antik Felsefe. çev. Suad Y. Baydur. İstanbul: Sosyal Yayınevi, 1994.

Kula, M. Naci. Gençlik Döneminde Kimlik ve Din. İstanbul: Ayıșığı Yayyıcılık, 2001.

Kuruçay, Yasin. Varoluşçu Felsefede Angst Kavramı. Bursa: Uludağ Üniversitesi Sosyal Bilimler Enstitüsü, Yüksek Lisans Tezi, 2001.

Kuş, Elif. Nicel- Nitel Araştırma Teknikleri. Ankara: Anı Yayıncılık, 2003.

Küçükcan, Talip - Ali Köse. Doğal Âfetler ve Din (Marmara Depremi Üzerine Psiko-Sosyolojik Bir İnceleme). 2000, İstanbul: TDV Yayınları, Akt. Güven, 2008.

Küng, Hans - K. J. Kuschel. Evrensel Bir Ahlâka Doğru. çev. N. Y. Aşıkoğlu vd. 1995.

Küng, Hans - Karl Josef Kuschel. Evrensel Bir Ahlâka Doğru. çev. Nevzat Y. Aşıkoğlu vd. Ankara: Gün Yayıncllık, 1995.

Maslow, Abraham. Dinler, Değerler, Doruk Deneyimler. çev. H. Koray Sönmez. Kuraldışı Yayınevi, 1996. 
Mckenzie, Leon. "The purposes and scope of adult religious education". In Handbook of Adult Religious Education, Ed. N. T. Foltz. Birmingham: AL. Religious Education Press. 1986, 7-23. https:// doi.org/10.1017/s0360966900024555

Özakpınar, Yılmaz. İnsan, İnanan Bir Varlı. İstanbul: Ötüken Neşriyat, 1999.

Özkan, Osman. Öfke Kontrolü ve Dindarlı İlişkisi. Isparta: Süleyman Demirel Üniversitesi Sosyal Bilimler Enstitüsü, Yüksek Lisans Tezi, 2016.

Park Crystal L. "Din ve Anlam”. çev. İlker Yenen. Din ve Maneviyat Psikolojisi Yeni Yaklaşımlar ve Uygulama Alanları içinde, derleyen. Raymond F. Paloutzan-Crystal L. Park, Ankara: Phoenix Yayınevi, 2013.

Pargament, Kenneth, I. “God Help Me: Toward a Theoretical Framework of Coping for the Psychology of Religion". Research in the Social Scientific Study of Religion. 2 (1980), 204-205, Akt. Bahadır, 2011:150. doi: 10.1007/BF00938065, https://doi.org/10.1037/e584032009-002

Pargament, Kenneth, I. "The Psychology of Religion and Spirituailty? Yes Or No". The International Journal for The Psychology of Religion 9/1 (1999), 3-16. doi: 10.1207/s15327582ijpr0901_2

Pargament, Kenneth, I. - H. G. Koenig vd. "The Many Methods of Religious Coping: Development and Initial Validation of The RCOPE”. Journal of Clinical Psychology 56/ 4 (2000), 519-543.

Pargament, Kenneth, I. - C. L. Park. "In Times of Stress: The Religion- Coping Connection”. Edt. B.Spilk and D. N. McIntosh, The Psychology of Religion içinde, USA, Colorado: Westview Press, 1997. doi: $10.4324 / 9780429495915-4$

Prager, Dennis. Mutluluk Ciddi Bir Sorundur. çev. Orhan Tuncay. İstanbul: Alkım Yayınevi, 1998.

Seggie Fatma Nevra - Yasemin Bayyurt. Nitel Araştırma Yöntem, Teknik, Analiz ve Yaklaşımları. Ankara: Anı Yayıncllık, 2015.

Seligman, Martin - E. P. M. Csikszentmihalyi. "Positive Psychology: An Introduction”. American Psychologist, 55, (2000), 5-14. doi: 10.1037/0003-066X.55.1.5

Serdar, Ziyauddin. Postmodernizm ve Öteki. İstanbul: Söylem Yayınları 2001.

Sezen, Abdulvahid. “Günümüz İnsanının Anlamsızlık Sorunu Bağlamında Frankl ve Fowler'da Bireyin Anlam Arayışı”. Sosyal Bilimler Araştırma Dergisi 7/14 (Eylül 2009), 189-201.

Snyder, Charles Richard - D. B. Feldman vd. "Hopeful Choices: A School Counselor's Guide To Hope Theory". Professional School Counseling, 5 (5), (2002), 298-307.

Soderstrom, D. - Wright, E. "Religion Orientation and Meaning in Life". Journal of Clinical Psychology 33 (1977), 65-68. https://doi.org/10.1002/1097-4679(197701)33:1+<65::AID-JCLP22703 $30113>3.0 . \mathrm{CO} ; 2-0$

Sokrates. Sokrates'in Savunması. çev. Teoman Aktürel. İstanbul: Remzi Kitabevi, 2004.

Steger, Michael F. “Making Meaning in Life”. Psychological Inquiry, 23(4), (2012), 381-385.

Steinberg, Laurence. Ergenlik. çev. Figen Çok. İstanbul: İmge Kitapevi, 2007.

Stríženec, Michal. "Dindarlık ve Bilişsel Süreçler”. çev. Abdulvahid Sezen. Dinbilimleri Akademik Araştırma Dergisi 10/3 (2010), 273 -286.

Tolstoy, Lev. N. İtiraflarım. çev. K. Aytaç. İstanbul: Furkan Yayınevi, 1997.

TÜIK, Türkiye İstatistik Kurumu. İstatistiklerle Gençlik 2016. (04 Ocak 2018). http://www.tuik.gov. tr /PreHaberBultenleri.do?id=24648

TÜIK, Türkiye İstatistik Kurumu, Boșanma Oranları. (05 Şubat 2020). http://www.tuik.gov.tr/Pre Tablo.do?alt_id=1059\#

Vergote, Antoine. “Çocuk ve Din”. çev. Erdoğan Fırat. Ankara Üniversitesi İlahiyat Fakültesi Dergisi 22 (1978), 315-329. https://doi.org/10.1501/ilhfak_0000000281

Vergote, Antoine. Din, İnanç ve İnançsızlı. çev. Veysel Uysal. İstanbul: Marmara Üniversitesi İlahiyat Vakfi Yayınları, 1999. https://doi.org/10.15370/muifd.66055 
Yalom, İrvin, D. Varolusçu Psikoterapi. çev. Zeliha İyidoğan Babayigit, İstanbul: Kabalcı Yayınları, 1999.

Yavuzer, Haluk. Çocuk Psikolojisi. İstanbul: Remzi Kitapevi, 1999.

Yeğin Hüseyin. “Öfke Duygusu ve Dini Açıdan Baş Edebilme Yolları”. Din Bilimleri Akademik Araştırma Dergisi 10/2 (2010), 235-258.

Yıldırım, Ali-Şimşek, Hasan. Sosyal Bilimlerde Nitel Araştırma Yöntemleri. Ankara: Seçkin Yayınc1lik, 2013.

Yıldız, Murat. İnsanların Ölüm Karsısındaki Tutumları Hakkında Yapılan Araștırmaların Değerlendirilmesi. İzmir: 9 Eylül Üniversitesi Sosyal Bilimler Enstitüsü, Yüksek Lisans Tezi, 1994.

Yörükoğlu, Atalay. Gençlik Çağı, Ruh Sağlığı ve Ruhsal Sorunları. İstanbul: Özgür Yayınları, 2000. 